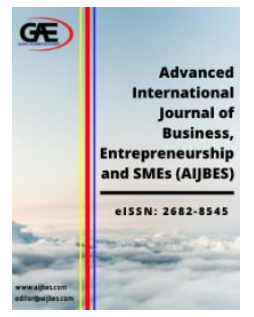

Advanced International Journal of Business, Entrepreneurship and SMEs (AIJBES)

Journal Website: http://aijbes.com/ eISSN: 2682-8545

\title{
NON-FINANCIAL SUPPORT STRATEGIES FOR START-UP HOMESTAY ENTREPRENEURS: AN EXPLORATORY CASE STUDY OF A SMALL ISLAND RURAL AREA OF INDONESIA
}

\author{
Hiroshi Kuwahara ${ }^{1}$ \\ $1 \quad$ Faculty Global and Reginal Studies, University of the Ryukyus, Japan \\ Email: kuwa@tm.u-ryukyu.ac.jp
}

\section{Article Info:}

Article history:

Received date: 03.02 .2020

Revised date: 31.03 .2020

Accepted date: 08.04 .2020

Published date: 10.06 .2020

\section{To cite this document:}

Kuwahara, H. (2020). Non-Financial Support Strategies for Start-up Homestay Entrepreneurs: An Exploratory Case Study of A Small Island Rural Area of Indonesia. Advanced International Journal of Business, Entrepreneurship and SMEs, 2 (4), 01-11.

DOI: $10.35631 / A I J B E S .24001$.

\begin{abstract}
:
This study explores non-financial support strategies for start-up homestay entrepreneurs in rural communities on a small island in Indonesia from the perspective of international development agents (IDAs). Semi-structured interviews were conducted with start-up homestay entrepreneurs regarding their needs, expectations of support, and the challenges of starting a business. A focus group interview was conducted with tourism experts with knowledge of the research area, to garner opinion about non-financial support strategies. Data from these different interview types were qualitatively interpreted and compared in order to triangulate the findings and develop effective assistance strategies. Three suggestions arise from the research findings. First, support for entrepreneurs with experience of working in tourism-related businesses should be as specific as possible, following a preliminary consultation. Second, support for entrepreneurs with no experience of working in tourism-related businesses should include the provision of information about the key components of tourism, including tourists, hospitality, the tourism business, and homestays, with hands-on activities. Third, IDAs should develop a support system that includes family business-oriented entrepreneurs who have been relatively neglected by conventional support programs aimed at capacitybuilding in developing countries.
\end{abstract}

Keywords:

International Development, Family Business, Capacity Development, Wakatobi

\section{Introduction}

For over a decade, international organizations, such as the United Nations World Tourism Organization (2006) and the International Labor Organization (Weinz \& Servoz, 2011), have recognized and promoted the role of the tourism industry in reducing poverty in developing 
countries. The importance of entrepreneurship in the tourism industry of developing countries has also been advocated (Echtner, 1995; Kirsten \& Rogerson, 2002), as entrepreneurs in developing countries are highly effective in reducing poverty (Goodwin, 1998).

However, entrepreneurial activities in rural areas of developing countries have remained underdeveloped due to limited access to source markets in metropolitan centers (Goodwin, 1998; Mair \& Marti, 2007). Fabeil, Mahmud, Hui, \& Mail (2017) report that people in Malaysia's rural islands believe that many challenges have to be overcome in order to start a business. External challenges include unsatisfactory physical infrastructure and lack of financial resources, while internal obstacles include lack of favorable personality traits, such as passion and self-confidence, and lack of business skills. In addition, their study found that local people believe that lack of external support is the main obstacle to participation in entrepreneurial activities. In other words, rural people in developing countries expect external intervention to support their entrepreneurship. Thus, the primary issue for external development organizations in the support of entrepreneurial activities in rural areas in developing countries is identifying collaborative methods that enable effective work with local entrepreneurs (Carlisle, Kunc, Jones, \& Tiffin, 2013).

Meanwhile, ever since Dr. Muhammad Yunus founded the Grameen Bank in Bangladesh to offer microcredit services in 1983, financial support for entrepreneurs in rural industries in developing countries has focused on micro financing systems (Grameen Bank, 2019). Positive outcomes have been reported for the role of microcredit programs in tourism businesses in rural areas of developing countries (Panjaitan-Drioadisuryo \& Cloud, 1999). In addition, nonfinancial support strategies for entrepreneurs in the rural areas of developing countries have also been reported as quite important (Fabeil et al., 2017), despite being relatively undervalued. In particular, starting a tourism business requires many kinds of marketing and service skills that rural people in developing countries often lack, as most potential guests are assumed to be urban residents, or from economically developed countries. Therefore, this paper discusses non-financial support strategies for tourism entrepreneurs in rural areas of developing countries.

Homestay tourism is a potential economic development strategy for the poor, offering the promise of jobs and additional income, with minimum capital requirements (Kwaramba, Lovett, Louw, \& Chipumuro, 2012). The economic benefits of a homestay business are expected to go directly to the homeowner (ASEAN Secretariat, 2016). Furthermore, homestay tourism has great market potential, as it is an experiential form of tourism that has become increasingly popular among tourists from developed countries (ASEAN Secretariat, 2016).

Homestay tourism is regarded as a sustainable form of tourism because it is low scale, low density, flexible, and spontaneous. It does not exploit existing traditional cultures or natural environments, particularly in rural areas (Acharya \& Halpenny, 2013; ASEAN Secretariat, 2016). In fact, homestay development in rural areas is now a widely implemented government policy in many developing countries, including Malaysia, Thailand, India, and South Africa (Bhan \& Singh, 2014; Kontogeorgopoulos, Churyen, \& Duangsaeng, 2015; Kunjuraman \& Hussin, 2017; Kwaramba et al., 2012).

However, external and government support for the development of homestay tourism programs face serious practical challenges in many areas. Capacity-building training courses in business and marketing skills should be provided by external agents at a very early stage to entrepreneurs and managers of homestay projects, as most work in primary industries and have limited 
tourism experience. However, Kunjuraman and Hussin (2017) report that a training course in remote villages of Sabah in Malaysia failed to achieve the expected outcomes, despite being offered at the beginning of the project. The course failed because it was not suited to trainees with only very basic levels of education. The authors also pointed out that the training course did not meet the continuous and on-going needs of the local people.

Soon after they are ready to welcome guests, homestay entrepreneurs must approach potential customers who are likely to be urban or developed country residents. However, external homestay project stakeholders, such as governments, international development agencies, tourism intermediaries, and other non-government bodies, are poorly coordinated (Bhan \& Singh, 2014; Kunjuraman \& Hussin 2017). Therefore, in rural areas of developing countries, non-financial support for homestay entrepreneurs by external agents continues to be a process of trial and error, and further exploration of effective strategies for the provision of nonfinancial support is required.

This paper focuses on non-financial support strategies for start-up homestay entrepreneurs in rural areas of Indonesia from the perspective of international development agents (IDAs), which was defined in the paper as international governmental and non-governmental development organizations related to tourism. The paper employs the following comprehensive definition of "homestay": "types of accommodation where tourists or guests pay to stay in private homes, where interaction takes place with a host and/or family usually living upon the premises, and with whom public space is, to a degree, shared" (Lynch, 2005). This definition applies to a variety of types of homestay accommodation across Indonesia's regions (Moscardo, 2009). Furthermore, the paper focuses on start-up entrepreneurs, as this group occupies a critical phase in the realization of successful business practices.

\section{Methods}

\section{Research Strategy}

Non-financial support strategies for start-up homestay entrepreneurs in the rural areas of less economically developed countries should consider the unique socioeconomic background of the entrepreneurs, and local tourism developments, including national tourism plans, as tourism planning and development policy are highly centralized in many developing countries (Tosun $\&$ Timothy, 2001). To explore these strategies, a case study method was employed that allowed the researcher to both deeply and multilaterally understand the complex context (Hartley, 2004).

This case study consisted of two types of interviews, conducted in June and July 2018. Semistructured interviews were conducted with start-up homestay entrepreneurs, and a focus group interview (FGI) was conducted with tourism researchers working in the region. The semistructured interviews explored start-up homestay entrepreneurs' specific needs for nonfinancial support, while the FGI was organized to collect opinions about assistance strategies from tourism experts with knowledge of the local situation. Data from both interview types were qualitatively interpreted and compared in order to triangulate information on the development of effective assistance strategies.

\section{The Case Study Area}

The research was conducted in Wakatobi Regency, a series of small islands located in the southeast of Indonesia's Sulawesi province (See Figure 1). In 2018, the population of Wakatobi Regency was 95,737 (Badan Pusat Statistik Kabupaten Wakatobi, n.d.). The majority of island 
inhabitants are employed in primary sector industries. However, interviews with the start-up entrepreneurs revealed that, similar to other rural regions of Indonesia, foreign emigration is common. The poverty rate in the regency in 2018 was $14.85 \%$, which is higher than the average provincial rate of $11.63 \%$ (Badan Pusat Statistik, n.d.).



Figure 1: Geographical Location of Wakatobi Islands, Indonesia

Source: Upper map from the Australian National University CartoGIS CAP 00-152, (Cropped), Lower map from PloS One, (Edited),

https://journals.plos.org/plosone/article/figure/image?size=large\&id=10.1371/journal.pone.0098694.g001

This area's main attractions include marine-based activities and natural and cultural heritage sites, such as Wakatobi National Park, which possesses some of Indonesia's greatest marine biodiversity. Traditional Lariangi dance in Kaledupa Island and Balumpa dance in Tomia Copyright (C) GLOBAL ACADEMIC EXCELLENCE (M) SDN BHD - All rights reserved 
Island are aspects of cultural heritage occasionally performed for visitors (Wakatobi Tourism Authority, n.d.)

As of 2018, only a small number of accommodation service providers had any contact information available on the Internet, even though, in 2016, The Ministry of Tourism Indonesia assigned Wakatobi Regency as one of ten priority tourist destinations (Antaranews.com, 2016). The regency received 3,315 in 2013 and, with investment, this number was expected to increase to 50,000 in 2019 (Indonesia-investment.com, 2018).

\section{Research Design and Methods}

\section{Semi-structured Interview with Start-up Homestay Entrepreneurs}

The start-up entrepreneurs interviewed for this research were at the opportunity identification stage of developing their businesses and were in the process of making decisions to exploit the opportunities they identified (Shook, Priem, \& McGee, 2003; Drnovšek, Wincent, \& Cardon, 2010). Two operational criteria were used to screen homestay entrepreneurs for interview. The first criterion was those who explicitly stated that they planned to start a homestay business. The second criterion was that these individuals had already taken specific actions to develop a homestay business, such as expanding their home, remodeling rooms for guests, and making a model of their house/room for development.

Of the interview candidates who satisfied these two criteria during a preliminary survey of the research area, interview participants were selected according to two relevant attributes of tourism entrepreneurship in rural areas of developing countries, so that their need for nonfinancial assistance could be explored. The first attribute was previous experience working in a tourism-related business. Business inexperience is a major difficulty faced by tourism-related entrepreneurs when starting businesses in rural areas of developing countries (Banki \& Ismail, 2015). The second attribute was a family business orientation or a community-based tourism (CBT) orientation. Ahmad, Jabeen, \& Khan (2014) have found that homestay entrepreneurs in Malaysia are strongly motivated by community participation and by factors related to family business. It was expected that interviewing start-up homestay entrepreneurs with distinctive characteristics would yield rich information to help in the more efficient development of assistance strategies.

Start-up homestay entrepreneurs were not easily identifiable, as homestay tourism is offered by a very limited number of families in the area. As a result, only four respondents were intentionally selected. Each interviewee belonged to a different community. Therefore, it was assumed that responses were not influenced by internal power structures within communities. Interviewee profiles are shown in Table 1.

Table 1: Profiles of Start-up Homestay Entrepreneur Interviewees

\begin{tabular}{|c|cc|cc|}
\hline & \multicolumn{2}{|c|}{ Family Business-Oriented } & \multicolumn{2}{c|}{ CBT-Oriented } \\
\hline With & \multicolumn{2}{|c|}{ Subject-A } & \multicolumn{2}{c|}{ Subject-B } \\
Experience & Sex: & Male & Sex: & Female \\
Working in & Age: & $30 \mathrm{~s}$ & Age: & $40 \mathrm{~s}$ \\
Tourism- & Educational & High School & Educational & High School \\
Related & Background: & & Background: & \\
Business & Occupation: & Car Rental & Occupation: & Homemaker/CBT \\
& & \multicolumn{2}{|c|}{ Operator } & \multicolumn{2}{c}{ Leader } \\
\hline
\end{tabular}




\begin{tabular}{|c|cc|cc|} 
With No & \multicolumn{2}{|c|}{ Subject-C } & \multicolumn{2}{c|}{ Subject-D } \\
Experience & Sex: & Female & Sex: & Male \\
Working in & Age: & 30s & Age: & 20s \\
Tourism- & Educational & Middle School & Educational & High School \\
Related & Background: & & Background: & \\
Business & Occupation: & Homemaker & Occupation: & Youth Group \\
& & & & Leader \\
\hline
\end{tabular}

Semi-structured interviews were conducted to explore the support needs and challenges of starting a homestay business, as well as expectations of support, and details of each homestay business. The interviewer, the author of this paper, addressed the following five topics during each interview: (i) recognition and attitude toward the homestay business; (ii) intention to start a homestay business; (iii) expectation and vision of the homestay business, (iv) threats and challenges to starting a homestay business; and (v) expectation of support. With the aid of an Indonesian-English interpreter with experience working for international non-governmental organizations in the area, four entrepreneurs were interviewed. Each interview lasted approximately 60 minutes.

\section{FGI with Tourism Researchers}

FGI participants were expected to provide practical information and suggestions for support strategies for start-up homestay entrepreneurs, based on their rich knowledge and experience of tourism in Indonesia. Five Indonesian tourism researchers working in Makassar City, on Sulawesi Island, were recruited. The author moderated the FGI, which was conducted in English. During the FGI, assistance methods and strategies for start-up homestay entrepreneurs in the research area were discussed. One FGI participant also took on the role of facilitator. It was emphasized that practical advice of non-financial supports for start-up homestay entrepreneurs in Wakatobi Regency was the objective of the FGI at the very beginning of interviewing the participants. The following topics were addressed: (i) recognized cases of foreign assistance in tourism development of Indonesia; (ii) advise to IDAs regarding assistance strategies and methods for start-up homestay entrepreneurs in the area; and (iii) expectations of IDAs' assistance activities that domestic development agents are unable to provide.

\section{Findings and Implications}

Qualitative data from the semi-structured interviews with start-up homestay entrepreneurs were used to develop hypothetical strategies for IDAs' assistance, while qualitative data from the FGI with tourism researchers was used to triangulate these strategies.

\section{Strategies for Entrepreneurs with Experience of Working in Tourism-Related Business}

All interviewees expressed a need for assistance in developing the basic knowledge and skills required to offer services, together with advice regarding the marketing and management of a homestay business. However, interviewees with experience of working in tourism-related businesses suggested that they could overcome some of these challenges alone. For example, these entrepreneurs had adopted specific ways to attract initial customers by using networks they had established during their previous business practices. Subject-A, the family businessoriented entrepreneur, described attracting initial guests: "I have name cards for my customers with a car rental since I started the business. So, I can contact them. I can also provide homestays for travelers who come to this island from the neighboring island in the morning. They may be looking for a place to stay." Subject-B, the CBT-oriented entrepreneur, also 
suggested that some participants on their current community daytime tour might become the first guests of their homestay business.

Subject-A and Subject-B recognized specific weak and strong points. Therefore, they had in mind a specific type of homestay management assistance that they wanted to receive. SubjectA pointed out the importance of digital marketing to attract foreign guests and expressed a willingness to receive assistance in developing digital skills. Subject-B said that matching guests to community members and allocating guests to community members fairly would be a challenge if they started a homestay business.

These entrepreneurs had a specific vision for their businesses and some capacity to develop the businesses by themselves. Their business plans included an assessment of their own abilities, as well as those of family members and the wider community. Therefore, IDAs could offer effective assistance once they had listened carefully to the challenges faced by homestay entrepreneurs and could identify the problems that the entrepreneurs could not resolve alone. In other words, non-financial assistance should focus on business consultation rather than standardized homestay business courses. In this way, IDAs could encourage entrepreneurs to utilize their existing abilities as much as possible (Bolger, 2000). When the assistance for those entrepreneurs is implemented by skill training, a "key missing ingredient" should be provided (Bennell, 1999).

Strategies for Entrepreneurs with No Experience of Working in Tourism-Related Business Subject-C and Subject-D, who had no experience of working in tourism-related businesses, agreed that they needed to develop comprehensive skills to run a homestay business, including hospitality skills, marketing skills, management skills, and English communication skills. Thus, IDAs should provide these entrepreneurs with capacity-building courses following the typical standards of homestay businesses, as suggested by ASEAN (ASEAN Secretariat, 2016). However, FGI participants emphasized that the most important course components should explain essential tourism concepts, such as what tourism is, what tourists are, and what a homestay is, as tourism is a completely new idea and practice to many local people in the area. FGI participants strongly recommended workshop-style training methods with hands-on activities from the beginning. In essence, it remains useful to employ traditional teaching techniques in tourism entrepreneur training in developing countries, which include case studies, real-life projects, experiential exercises, and field trips to existing businesses (Echtner, 1995; Loucks, 1988). In addition, essential requirements for hospitality businesses, such as good hygiene, can be taught through the enforcement of practices in daily life (Kuwahara, 2014).

\section{Strategies for Entrepreneurs with a Community Business Orientation}

Subject-D confessed that it was very difficult to make the elder leader of his community understand the significance of homestay businesses, although it was essential to develop a community homestay project. Subject-B said that some members were ready to accept homestay guests, but she had not decided when to start the business because she was unable to find a "correct" way to distribute guests among community members. FGI participants suggested that IDAs should offer assistance to entrepreneurs after they have approached community leaders and agreed with them which types of assistance activities are required. It is not unusual that there are important differences of interests even in apparently homogeneous local community (Shirlow \& Murtagh, 2004). External agents should fully respect community power structures and relationships when offering assistance to start-up homestay entrepreneurs with a CBT orientation, as rural communities in developing countries are often governed by 
unique decision-making systems that may well differ from contemporary democratic principles (Manyara \& Jones, 2007; Platteau \& Abraham, 2002).

\section{Organizational Implications for IDAs}

When organizing a support team, FGI participants suggested that IDAs may be able to organize objective-oriented teams to offer support to entrepreneurs, rather than domestic development professionals, as IDAs are relatively independent of local power structures. Local tourism researchers recognized that part of the reason that the support offered by domestic development agents, including government organizations, has failed to achieve rural development objectives is the inefficient structure of agents' teams. IDAs should, as much as possible, organize functional support teams through a fair employment process.

A number of homestay entrepreneur studies have been conducted in the context of CBT (Kunjuraman \& Hussin, 2017; Sood, Lynch, \& Anastasiadou, 2017). This may be because external interventions have tended to view communities as recipients of support, resulting in the role of tourism entrepreneurs and tourism entrepreneurship being under-addressed (Koh \& Hatten, 2002). However, the nature of community power structures differs from community to community. Relationships between start-up homestay entrepreneurs and other community members are highly varied. Some start-up homestay entrepreneurs, such as the family-oriented Subject-A, are relatively independent of community cohesion. He explained that he could not imagine who might offer him support to develop his digital marketing skills at the moment, even though he recognized the importance of these skills in attracting foreign guests to the homestay. Conventional IDAs' support may overlook entrepreneurs who remain marginal to community power structures. Therefore, IDAs need to develop support systems that include family business-oriented entrepreneurs who have been neglected by conventional capacitybuilding support programs.

Typically, in developing countries, tourism development policies and programs in rural areas are planned and implemented by central government. As such, they tend to be formulaic, and pay little attention to variation in rural situations (Tosun, 1998; Tosun, 2001). FGI members agreed that assistance programs organized in rural areas by Indonesian government agents have often been implemented in respect to the completion of programs, rather than their outcomes. Continuity of the assistance program as capacity building have not generally been reconsidered and planned according to results of the initial program. In essence, bureaucratic planning by domestic government agents has hardly changed. The FGI participants agreed that IDAs' assistance should be more flexible to the unique situations of rural areas and the characteristics of assistance recipients.

\section{Research Limitations}

This study aimed to identify hypothetical assistance strategies for start-up homestay entrepreneurs in rural areas of developing countries. However, as it is a solitary case study, generalization of the strategies suggested requires further investigation in other areas.

\section{Acknowledgment}

This study was supported by JSPS KAKENHI Grant Number 16K02075. Special thanks to all the interviewees in Sulawesi. 


\section{References}

Acharya, B. P., \& Halpenny, E. A. (2013). Homestays as an alternative tourism product for sustainable community development: A case study of women-managed tourism product in rural Nepal. Tourism Planning \& Development, 10(4), 367-387.

Ahmad, S. Z., Jabeen, F., \& Khan, M. (2014). Entrepreneurs choice in business venture: Motivations for choosing home-stay accommodation businesses in Peninsular Malaysia. International Journal of Hospitality Management, 36, 31-40.

Antaranews.com (2016). Indonesia offering 10 main tourism destinations dubbed as "new balis". Retrieved from https://en.antaranews.com/news/103348/indonesia-offering-10main-tourism- destinations-dubbed-as-new-balis.html

ASEAN Secretariat (2016). ASEAN Homestay Standard. Jakarta, Indonesia: The ASEAN Secretariat.

Badan Pusat Statistik Kabupaten Wakatobi (n.d.). Number of Population by Age Group and Sex in Wakatobi Regency, 2016-2018. Retrieved from https://wakatobikab.bps.go.id/dynamictable/2019/10/15/80/jumlah-penduduk menurut-kelompok-umur-dan-jenis-kelamin-di-kabupaten-wakatobi-tahun-2016 2018.html

Badan Pusat Statistik, Statistics of Sulawesi Tenggara Province (n.d.). Retrieved from http://sultra.bps.go.id/linkTableDinamis/view/id/62

Banki, M. B., \& Ismail, H. N. (2015). Understanding the characteristics of family owned tourism micro businesses in mountain destinations in developing countries: Evidence from Nigeria. Tourism Management Perspectives, 13, 18-32.

Bennell, P. (1999). Learning to change: Skills development among the economically vulnerable and socially excluded in developing countries. Geneva, Switzerland: ILO.

Bhan, S., \& Singh, L. (2014). Homestay tourism in India: Opportunities and challenges. African Journal of Hospitality, Tourism and Leisure, 3(2), 1-5.

Bolger, J. (2000). Capacity development: Why, what and how. Capacity Development Occasional Series, 1(1), 1-8.

Carlisle, S., Kunc, M., Jones, E., \& Tiffin, S. (2013). Supporting innovation for tourism development through multi-stakeholder approaches: Experiences from Africa. Tourism Management, 35, 59-69.

Drnovšek, M., Wincent, J., \& Cardon, M. S. (2010). Entrepreneurial self-efficacy and business start-up: Developing a multi-dimensional definition. International Journal of Entrepreneurial Behavior \& Research, 16(4), 329-348.

Echtner, C. M. (1995). Entrepreneurial training in developing countries. Annals of Tourism Research, 22(1), 119-134.

Fabeil, N. F., Mahmud, R., Hui, J. N. L., \& Mail, R. (2017). Exploring the prospects and challenges for entrepreneurship among rural small island community in Sabah, Malaysia. Journal of Advanced Research in Business and Management Studies, 7(2), 69-77.

Goodwin, H. (1998). Sustainable tourism and poverty elimination. In DFID/DETR Workshop on Sustainable Tourism and Poverty. London: Department for International Development.

Grameen Bank. (2019). Founder. Retrieved from https://www.grameen-info.org/grameenfounder-muhammad-yunus/

Hartley, J. (2004). Case study research. In C. Cassell \& G. Symon (Eds.), Essential Guide to Qualitative Methods in Organizational Research, London: Sage.

Indonesia-investment.com (2018). Tourism Industry Indonesia: Gov't Seeks \$20 Billion of Investment. Retrieved from 
https://www.indonesia-investments.com/culture/culture-columns/tourism- industryindonesia-gov-t-seeks-20-billion-of-investment/item8518

Kirsten, M., \& Rogerson, C. M. (2002). Tourism, business linkages and small enterprise development in South Africa. Development Southern Africa, 19(1), 29-59.

Koh, K. Y., \& Hatten, T. S. (2002). The tourism entrepreneur: The overlooked player in tourism development studies. International Journal of Hospitality \& Tourism Administration, 3(1), 21-48.

Kontogeorgopoulos, N., Churyen, A., \& Duangsaeng, V. (2015). Homestay tourism and the commercialization of the rural home in Thailand. Asia Pacific Journal of Tourism Research, 20(1), 29-50.

Kunjuraman, V., \& Hussin, R. (2017). Challenges of community-based homestay programme in Sabah, Malaysia: Hopeful or Hopeless? Tourism Management Perspectives, 21, 1-9.

Kuwahara, H. (2014). Managing indigenous minority groups in the tourism industry: An exploratory case study in southern Laos. SHS Web of Conferences, 12, 01043.

Kwaramba, H. M., Lovett, J. C., Louw, L., \& Chipumuro, J. (2012). Emotional confidence levels and success of tourism development for poverty reduction: The South African Kwam eMakana home-stay project. Tourism Management, 33(4), 885-894.

Loucks, K. E. (1988). Entrepreneurship development in third world countries. Research Report No. 88-10-01A. St. Catherines: The Brock University Centre for Entrepreneurship. Retrieved from http://expertise.hec.ca/chaire_entrepreneuriat/wpcontent/uploads/88-10-01a- entrepreneurship-dvelopement.pdf

Lynch, P. A. (2005). Sociological impressionism in a hospitality context. Annals of Tourism Research, 32(3), 527-548.

Mair, J., \& Marti, I. (2007). Entrepreneurship for social impact: Encouraging market access in rural Bangladesh. Corporate Governance: The international journal of business in society, 7(4), 493-501.

Manyara, G., \& Jones, E. (2007). Best practice model for community capacity-building: A case study of community-based tourism enterprises in Kenya. Turizam: međunarodni znanstveno-stručni časopis, 55(4), 403-415.

Moscardo, G. (2009). Bed and breakfast, homestay and farmstay accommodation: Forms and experiences. In Commercial Homes in Tourism (pp. 45-57). New York: Routledge.

Panjaitan-Drioadisuryo, R. D., \& Cloud, K. (1999). Gender, self-employment and microcredit programs an Indonesian case study. The Quarterly Review of Economics and Finance, 39(5), 769-779.

Platteau, J. P., \& Abraham, A. (2002). Participatory development in the presence of endogenous community imperfections. Journal of Development Studies, 39(2), 104 $-136$.

Shirlow, P., \& Murtagh, B. (2004). Capacity-building, representation and intracommunity conflict. Urban studies, 41(1), 57-70.

Shook, C. L., Priem, R. L., \& McGee, J. E. (2003). Venture creation and the enterprising individual: A review and synthesis. Journal of Management, 29(3), 379-399.

Sood, J., Lynch, P., \& Anastasiadou, C. (2017). Community non-participation in homestays in Kullu, Himachal Pradesh, India. Tourism Management, 60, 332-347.

Tosun, C. (1998). Roots of unsustainable tourism development at the local level: The case of Urgup in Turkey. Tourism Management, 19(6), 595-610.

Tosun, C. (2001). Challenges of sustainable tourism development in the developing world: The case of Turkey. Tourism Management, 22(3), 289-303. 
Tosun, C., \& Timothy, D. J. (2001). Shortcomings in planning approaches to tourism development in developing countries: The case of Turkey. International Journal of Contemporary Hospitality Management, 13(7), 352-359.

United Nations World Tourism Organization. (2006). Tourism can help in poverty alleviation: What can you do? Madrid, Spain: UNWTO.

Wakatobi Tourism Authority (n.d.) The Official Tourism Website of Wakatobi. Retrieved from https://www.wakatobitourism.com/

Weinz, W., \& Servoz, L. (2011). Rural development through decent works stimulating rural growth, jobs and income through tourism. Rural Policy Brief, International Labour Organization.

Retrieved

from https://www.ilo.org/wcmsp5/groups/public/ed_emp/documents/publication/wcms_16 1153.pdf 